\title{
Halina Guzik
}

Katedra Gospodarki Regionalnej

Uniwersytet Ekonomiczny w Krakowie

Wojciech Strzelczyk

Studia Doktoranckie Wydziału Finansów

Uniwersytet Ekonomiczny w Krakowie

\section{Zagospodarowanie turystyczne jako ekonomiczny czynnik ksztaltowania produktu turystycznego obszaru}

\section{Streszczenie}

W artykule zwrócono szczególną uwagę na zagospodarowanie turystyczne jako jeden $\mathrm{z}$ istotnych elementów megaproduktu jednostki terytorialnej, który stanowi ważny czynnik ekonomiczny rozwoju produktu turystycznego obszaru/miasta. Celem artykułu jest wyjaśnienie roli zagospodarowania turystycznego w ocenie produktu turystycznego obszaru/miasta oraz ukazanie ekonomicznych aspektów gospodarowania przestrzenią turystyczną. Artykuł jest próbą przedstawienia kwestii dotyczących turystyki i produktu turystycznego obszaru w kontekście marketingu terytorialnego, który staje się szczególnie istotny $\mathrm{w}$ ramach podnoszenia przewagi konkurencyjnej regionu.

Słowa kluczowe: turystyka, zagospodarowanie turystyczne, megaprodukt, terytorialny produkt turystyczny. 


\section{Wprowadzenie}

Turystyka stanowi jedną z najbardziej dynamicznie rozwijających się dziedzin gospodarki w wielu krajach i jest istotnym czynnikiem rozwoju gospodarczego miast i regionów. Fenomenem turystyki jest aktywizacja wielu gałęzi gospodarki. Ma ona charakter wielowymiarowy, co pozwala na rozpatrywanie jej na wielu płaszczyznach. W niniejszym artykule zwrócono szczególną uwagę na zagospodarowanie turystyczne jako jeden $z$ istotnych elementów megaproduktu jednostki terytorialnej. Infrastruktura turystyczna stanowi jednocześnie ważny czynnik ekonomiczny rozwoju produktu turystycznego obszaru (miasta). Zastosowanie znajduje tu teoria kumulatywnej przyczynowości [Myrdal 1959], zgodnie z którą poprzez wzajemną interakcję zjawisk zaciera się granica pomiędzy tym, co stanowiło przyczynę, a tym co stanowiło skutek. W tym kontekście element może być czynnikiem, jak i czynnik może być elementem.

Problematyka zagospodarowania turystycznego osadzona w ekonomii jest ujmowana na dwa sposoby. Pierwszy dotyczy wartościowania przestrzeni turystycznej i kształtowania jej ceny na rynku. Wartość oceniana jest na gruncie efektywnego wykorzystania walorów turystycznych i zagospodarowania danej przestrzeni oraz ochrony jej unikatowości, cena zaś kształtowana jest na rynku nieruchomości jako efekt wpływu wielu czynników, np. lokalizacji czy dostępności usług. Zagospodarowanie turystyczne w procesie wartościowania i kształtowania ceny przestrzeni turystycznej stanowi kluczowy element determinujący wysokość badanych zmiennych. Drugi ekonomiczny sposób dotyczy bazy noclegowej jako podstawowego elementu zagospodarowania turystycznego.

Celem artykułu jest wyjaśnienie roli zagospodarowania turystycznego w ocenie produktu turystycznego obszaru/miasta oraz ukazanie ekonomicznych aspektów gospodarowania przestrzenią turystyczną. Kwestie dotyczące turystyki oraz produktu turystycznego obszaru starano się ukazać w kontekście marketingu terytorialnego. W warunkach rozwoju samorządności lokalnej wdrożenie koncepcji marketingu terytorialnego staje się szczególnie przydatne do podnoszenia przewagi konkurencyjnej w skali terytorialnej.

\section{Turystyka w kontekście koncepcji marketingowych}

Zastosowanie koncepcji marketingu w turystyce wymaga uwzględnienia specyficznych cech tego sektora gospodarki, wśród których można wymienić następujące [Kornak i Rapacz 2001, s. 125]:

- turystyka jest zjawiskiem nie tylko gospodarczym, lecz także społeczno-przestrzennym, co oznacza silny jej związek z obszarem mającym określone 
walory turystyczne, a także określone zasoby ludzkie i kulturę świadczenia usług;

- potrzeby turystów są zaspokajane przez towary i usługi oferowane przez podmioty gospodarcze należące do różnych gałęzi gospodarki. Ze względu na marketing istotne jest poznanie potrzeb zaspokajanych przez turystykę oraz cech ilościowych i jakościowych towarów i usług, które temu celowi służą;

- marketing w turystyce dotyczy tych działów usług, które oferują odwiedzającym różne świadczenia (np. nocleg, gastronomia, transport). Turystyka występuje jako czynnik stymulujący ich rozwój, odwiedzający są zaś specyficznym segmentem rynku usług;

- ze względu na posiadane walory turystyczne, komplementarne usługi i infrastrukturę analizowany powinien być nie tylko produkt oferowany przez przedsiębiorstwa turystyczne, lecz pełny produkt turystyczny danego regionu czy miejscowości (ogólnie obszaru).

Ze względu na specyfikę funkcjonowania sektora turystycznego, można brać pod uwagę zarówno marketing skierowany na podmioty gospodarki turystycznej, jak też marketing pewnego obszaru - jednostki przestrzennej, jak: miasto, gmina, region turystyczny itd. Ta druga kwestia jest przedmiotem dalszych rozważań i należy do dziedziny sektorowego marketingu terytorialnego.

Termin marketing terytorialny jest często przywoływany w literaturze przedmiotu, ale można zetknąć się z poglądami, że odpowiedniejsze byłoby określenie „zarządzanie marketingowe przestrzenią” lub „strategiczne zarządzanie terytorium" [Marketing terytorialny... 2005, s. 9-11; 33-34].

Marketing terytorialny obejmuje całokształt skoordynowanych działań podmiotów lokalnych, regionalnych lub ogólnokrajowych zmierzających do wykreowania procesów wymiany i oddziaływania poprzez rozpoznanie, kształtowanie i zaspokojenie potrzeb oraz pragnień mieszkańców [Szromnik 1997, s. 36]. Jako stosunkowo nowa dziedzina wiedzy jest rynkowo ukierunkowaną filozofią zarządzania gminą, w której władza lokalna zachowuje się w sposób przypominający prywatną korporację. Władze działają tak, aby miasto (złożony produkt, megaprodukt) zaspokoiło zidentyfikowane i antycypowane potrzeby klientów w zamian za uzyskane korzyści dla określonego terytorium traktowanego jako terytorialnie upodmiotowiony zbiór mieszkańców.

Wzrost zdolności konkurencyjnej pewnej wyodrębnionej przestrzeni (miasta, gminy, regionu) jest celem marketingu terytorialnego. Przestrzeń konkurencyjna jest ,wyposażona w sprawną infrastrukturę techniczną i społeczną, jak również w instytucje wspierające działalność gospodarczą [...]. To również przestrzeń o silnie rozbudowanych powiązaniach zewnętrznych i wewnętrznych. To wreszcie przestrzeń sprawnie zarządzana, dla której istnieje i jest realizowany długofalowy, strategiczny, wizjonerski program rozwoju" [Szromnik 2002, s. 21]. 
Biorąc pod uwagę zakres przestrzenny niniejszych rozważań szczególną uwagę zwraca się na marketing terytorialny miast, który jest „rynkowo zorientowaną koncepcją zarządzania miastem przez władze samorządowe i jej partnerów w celu zaspokojenia obecnych i przyszłych potrzeb użytkowników (klientów) wewnętrznych i zewnętrznych. Sens ekonomiczny marketingu miasta przejawia się w wyznaczaniu jego bazy ekonomicznej oraz większych dochodach ekonomicznych" [Markowski 1997, s. 52]. Można zatem wymienić następujące jego cechy (ujęcie szerokie):

- podnoszenie konkurencyjności miasta,

- przyciąganie zewnętrznych inwestorów,

- poprawa i kształtowanie wizerunku,

- podnoszenie dobrobytu mieszkańców,

- tworzenie atrakcyjnych warunków dla działalności gospodarczej mieszkańców poprzez wykreowanie zasobów endogenicznych,

- wzrost atrakcyjności turystycznej.

$\mathrm{Z}$ istoty marketingu terytorialnego wynika, że dla odbiorców dane terytorium stanowi nie tylko „miejsce”, ale też sumę korzyści, jakie oferuje w stosunku do konkretnych lokalizacji. Traktowanie miejsca jako podstawy przewagi konkurencyjnej przez kreowanie produktu nabiera szczególnego znaczenia w turystyce, w której rola przestrzeni i związanego $\mathrm{z}$ nią środowiska przyrodniczego jest zdecydowanie ważniejsza niż w wielu innych dziedzinach [Niezgoda 2006, s. 64].

Obszar recepcji turystycznej może być postrzegany jako zbiór określonych funkcji oraz jako pewien produkt (megaprodukt) mający wiele cech o różnej jakości i użyteczności dla użytkowników, których grupę stanowią odbiorcy „wewnętrzni” (mieszkańcy) i „,zewnętrzni” (turyści)”.

\section{Obszarowy produkt turystyczny jako element megaproduktu miasta}

Ze względu na marketing miasta należy na nie spojrzeć $\mathrm{z}$ dwu poziomów agregacji, tj. na miasto jako całość - specyficzny megaprodukt oraz na podzbiór subproduktów miejskich. Elementami megaproduktu są przede wszystkim: wizerunek miasta, lokalny klimat kulturalny, klimat przedsiębiorczości, zdolność do samoorganizacji i tworzenia sieciowych powiązań między podmiotami, a także system komunikacyjny i jakość zagospodarowania. Te elementy są trudne do identyfikacji przez konkurentów i często stanowią o przewadze konkurencyjnej jednostki terytorialnej. Koncepcja miasta jako megaproduktu jest bardzo ważna ze względu na jego rozwój, bowiem związana jest z potrzebą budowania wizerunku miasta jako całości. Wizerunek to niematerialna, zapisana w zbiorczej 
kulturze stereotypowa wiedza i percepcja o danym obszarze. Bardzo trudno jest zmienić obraz miasta już raz zachowany w świadomości danego człowieka [Markowski 1997, s. 52].

Megaprodukt miejski (miasta) jest kategorią funkcjonującą w obszarze zainteresowań marketingu terytorialnego. Zgodnie z definicją zaprezentowaną w „Słowniku rozwoju regionalnego”, megaprodukt regionalny to „uporządkowana oferta wzajemnie powiązanych zasobów lub produktów, wytworzona dzięki umiejętnie zatrudnionym czynnikom i zasobom produkcji, których konsumpcja i wykorzystanie produkcyjne jest związane z danym regionem" [Kozak, Pyszkowski i Szewczyk 2000, s. 29]. Megaprodukt miejski będący sumą składników materialnych i niematerialnych produktów cząstkowych (subproduktów funkcjonalnych np. produkt turystyczny, inwestycyjny, mieszkaniowy itp.), stanowi sumę potencjalnych korzyści oferowanych konkretnemu nabywcy w wyniku procesu wymiany. Charakteryzuje się on ogromną złożonością i wpływem aspektów historycznych, ciągłą zmiennością, różnym znaczeniem poszczególnych jego części dla różnych „użytkowników” oraz kluczowym znaczeniem efektów zewnętrznych. Strukturę megaproduktu miejskiego prezentuje rys. 1.

\begin{tabular}{|c|c|c|}
\hline \multicolumn{3}{|c|}{ Megaprodukt miejski } \\
\hline Czynnik materialny & Czynnik niematerialny & Czynnik naturalny \\
\hline Infrastruktura techniczna & Plany i koncepcje rozwoju & Położenie geograficzne \\
\hline Infrastruktura społeczna & „Klimat społeczny” & Klimat \\
\hline Budynki mieszkalne & Wizerunek miasta & Ukształtowanie terenu \\
\hline $\begin{array}{c}\text { Budynki przemysłowe } \\
\text { i usługowe }\end{array}$ & Historia i tradycje & Atrakcje przyrodnicze \\
\hline Suprastruktura & Rynek pracy i edukacji & \multirow{2}{*}{ Bliskość jezior, rzek i morza } \\
\hline Istniejące firmy i organizacje & Nazwa miasta oraz symbolika & \\
\hline \multicolumn{3}{|c|}{ Zagospodarowanie przestrzenne } \\
\hline \multicolumn{3}{|c|}{ Tożsamość miasta } \\
\hline
\end{tabular}

Rys. 1. Struktura megaproduktu miasta

Źródło: [Wołek 2010].

Miasto o określonej tożsamości, rozwija atrakcyjność lokalnego produktu turystycznego będącego składową megaproduktu. Produkt turystyczny nabiera coraz większego znaczenia jako instrument działań marketingowych w świetle rosnącej konkurencji na rynku turystycznym. Sukces rynkowy mogą odnieść tylko te jednostki przestrzenne (miasta, regiony itd.), które zaoferują atrakcyjny produkt turystyczny. W konsekwencji atrybutem staje się jakość wszystkich elementów, które ten produkt tworzą. 
W literaturze przedmiotu definiuje się najczęściej produkt, jako „zbiór użyteczności związanych z podróżami turystycznymi, czyli dostępne na rynku dobra i usługi turystyczne, umożliwiające ich planowanie, odbywanie, przeżywanie oraz gromadzenie doświadczeń z nimi związanych" [Kaczmarek, Stasiak i Włodarczyk 2005, s. 74]. W myśl teorii marketingowych produktem jest wszystko co oferowane jest na rynku jako godne uwagi, nabycia lub konsumpcji dla zaspokojenia potrzeb i wymagań konsumenta [Kotler, Brower i Makers 1999, s. 14]. Interdyscyplinarność i heterogeniczność zjawiska turystyki potwierdza fakt, że nie ma jednego typu produktu, występują natomiast bardzo różnorodne jego rodzaje, takie jak: produkt turystyczny rzecz, usługa, pakiet usług, wydarzenie, impreza, obiekt, szlak, obszar [Kaczmarek, Stasiak i Włodarczyk 2005, s. 76].

Z uwagi na zakres rozważań scharakteryzowania wymaga ostatni typ produktu turystycznego. Pojęcie produktu turystycznego obszaru powstało w konsekwencji rozwoju marketingu miejsc. Produkt turystyczny - obszar jest produktem szczególnym, uwarunkowanym przestrzennie, złożonym z wybranych elementów potencjału turystycznego danego obszaru, połączonych nadrzędną ideą decydującą o jego oryginalności, odrębności i atrakcyjności rynkowej [Kaczmarek, Stasiak i Włodarczyk 2005, s. 101]. Zdaniem wielu autorów produkt turystyczny obszaru traktuje się jako połączony rezultat atrakcji, udogodnień i usług oferowanych w miejscu docelowym.

Korzyści ekonomiczne i osiąganie satysfakcji przez nabywcę zależą bezwzględnie od „tworzywa” produktu, którym są zasoby i walory turystyczne oraz wytworzone na ich podstawie różnorodne dobra i usługi turystyczne. Mimo że podstawowe dobra turystyczne istnieją niezależnie od turystyki, to jednak stają się atrakcyjne dla odwiedzających w wyniku działań różnych podmiotów, które odpowiednio przygotowują, zagospodarowują i udostępniają je. Tak więc można stwierdzić, że podstawowe dobra turystyczne są tymi komponentami produktu, które wpływają na wybór przez potencjalnego turystę miejsca docelowego, natomiast urządzenia i usługi umożliwiające odwiedzającym pobyt poza miejscem stałego zamieszkania są tymi elementami regionalnego produktu turystycznego, które mimo że zazwyczaj (są nieliczne wyjątki) nie dostarczają motywacji do podejmowania podróży, to ich brak może powstrzymać od korzystania z niektórych nawet bardzo atrakcyjnych walorów, a niekiedy brak lub niska jakość bazy noclegowej mogą stać się istotną przeszkodą przyjazdu.

Infrastruktura regionu $\mathrm{z}$ jednej strony jest niezbędna, aby turysta mógł zaspokoić swoje podstawowe potrzeby bytowe, a z drugiej - może stać się podstawą samodzielnych atrakcji turystycznych lub produktów turystycznych dla takich typów turystyki, jak np. turystyka konferencyjna czy biznesowa. To właśnie szeroko rozumiany potencjał turystyczny obszaru jest podstawą tworzenia regionalnych produktów w turystyce. 
Powyższe stwierdzenie można odnieść także do miejskiego produktu turystycznego, czyli oferowanego przez konkretne miasto. Obszary miejskie mają często bardzo złożony i wielofunkcyjny charakter, a zatem elementy obszarowego produktu turystycznego w przypadku miast wydają się zdecydowanie bardziej zróżnicowane, a ich potencjał turystyczny obejmuje znacznie więcej elementów składowych niż ma to miejsce w przypadku innych jednostek przestrzennych (obszarów wiejskich lub typowych miejscowości recepcyjnych).

\section{Przestrzenne aspekty zagospodarowania turystycznego}

Szczególnym rodzajem miejsc recepcji turystycznej są miasta, co wynika z różnorodności przejawów aktywności turystycznej i roli, jaką turystyka odgrywa lub może odgrywać w szeroko rozumianym rozwoju miast oraz we współzależności między charakterem i funkcjami miast i turystyki. Miastotwórcza funkcja turystyki działa według zasady sprzężenia zwrotnego. Ruch turystyczny przyczynia się do rozwoju gospodarki danego ośrodka, czyniąc ją coraz lepiej przygotowaną do zaspokojenia potrzeb odwiedzających. W efekcie rozszerza się możliwość recepcji turystycznej miasta, wzrasta liczba turystów, aby z kolei jeszcze silniej stymulować rozwój społeczno-gospodarczy ośrodka turystycznego.

Tożsamość produktu turystycznego miasta należy więc rozważać w kontekście wymiarów znaczeniowych elementów, składających się na przestrzeń miejską i wyróżniających się elementów potencjału turystycznego [Bosiacki 2010, s. 43]. Specyfika miejskiej przestrzeni turystycznej polega na tym, że powstaje ona w związku z rozwojem funkcji turystycznej w przestrzeni miejskiej. W konsekwencji następuje rozkładanie się wielu różnych funkcji rozwijających się wspólnie na tej samej przestrzeni. Biorąc pod uwagę kryterium funkcjonalne oparte m.in. na skali oddziaływania i przekształceń, można wyróżnić charakterystyczne typy miejskiej przestrzeni turystycznej: penetracji, asymilacji, eksploracji, kolonizacji i urbanizacji [Kompendium wiedzy... 2002, s. 87].

Decyzja o rozwijaniu funkcji turystycznej danego obszaru jest podejmowana zwykle z nadzieją, że przyczyni się do aktywizacji gospodarczej regionu, co spowoduje wzrost zatrudnienia, dochodów ludności oraz wzrost wpływów do budżetów lokalnych. Dzieje się tak szczególnie w przypadku, gdy na danym terenie istnieje już pewne zagospodarowanie turystyczne. Wówczas w miejscowych planach zagospodarowania przestrzennego zauważa się wyraźnie starania o utrzymanie dotychczasowej rangi, funkcji i skali turystyki [Regionalne aspekty... 1999, s. 102].

Możliwość realizacji funkcji turystycznej zapewnia infrastruktura stanowiąca ważny element strukturalnego potencjału turystycznego, obejmująca wszelkie 
elementy materialne przestrzeni, takie jak np.: obiekty noclegowe, gastronomiczne, komunikacyjne. Istotną rolę odgrywa zróżnicowanie obiektów oraz ich usytuowanie w terenie, wkomponowanie w krajobraz i funkcjonalne powiązanie. Ważne jest takie zagospodarowanie turystyczne jeszcze niezainwestowanego obszaru, aby było możliwe wprowadzenie tam funkcji turystycznej. Znajomość tych zasad ma zasadnicze znaczenie dla właściwie rozumianej gospodarki przestrzennej we wszystkich jej wymiarach.

Specyfika infrastruktury turystycznej będącej ważnym komponentem megaproduktu miasta w znacznym stopniu determinuje możliwość osiągania przez miasto przewagi konkurencyjnej, jednocześnie trwale wpływając na zagospodarowanie przestrzeni i jakość życia w mieście. Rys. 2 przedstawia uproszczony schemat megaproduktu miasta, eksponując bazę noclegową jako jeden $\mathrm{z}$ bardzo ważnych elementów zagospodarowania turystycznego.

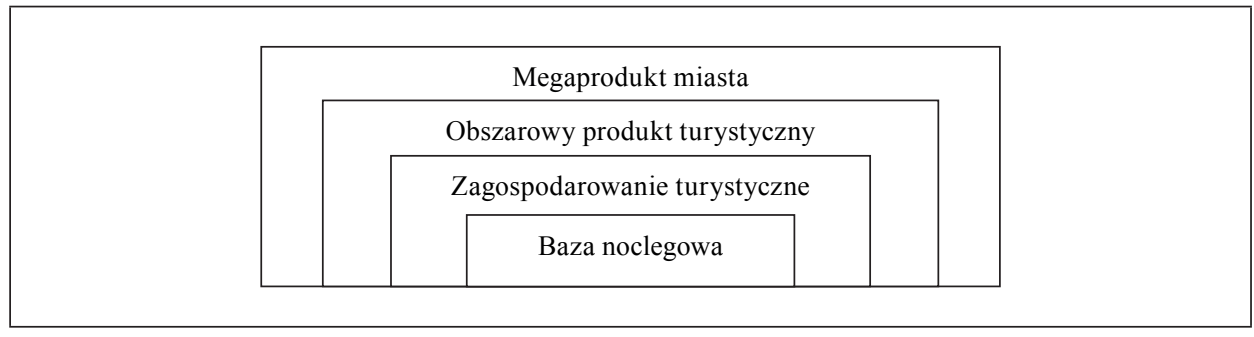

Rys. 2. Baza noclegowa elementem megaproduktu miasta Źródło: opracowanie własne.

Jak twierdzi W. Kurek, „,czynnikiem przemian przestrzennych nie jest już bezpośrednio osoba turysty, lecz proces zagospodarowania turystycznego, którego celem jest przystosowanie przestrzeni na potrzeby ruchu turystycznego. W wyniku tego procesu powstają konkretne obiekty i urządzenia turystyczne oraz adaptowane do określonych form turystyki tereny rekreacyjne" [Turystyka... 2007, s. 446].

Infrastruktura regionu z jednej strony jest niezbędna, aby turysta mógł zaspokoić swoje podstawowe potrzeby bytowe, $\mathrm{z}$ drugiej strony może stać się podstawą samodzielnych atrakcji turystycznych lub produktów turystycznych dla takich typów turystyki, jak turystyka kongresowa czy biznesowa.

Zagospodarowanie turystyczne jest jednym z najczęściej opisywanych zagadnień związanych z turystyką. Podkreślenia wymaga jednak fakt, że pojęcie to nie jest w literaturze przedmiotu definiowane jednoznacznie, jest też wymiennie stosowane przez poszczególnych autorów z takimi pojęciami, jak „baza mate- 
rialna turystyki” lub „,infrastruktura turystyczna”. Problemy dotyczą również rozpatrywania zagospodarowania turystycznego $\mathrm{w}$ aspekcie procesu lub stanu.

W literaturze przedmiotu w większości przypadków używana jest definicja, formułowana przez O. Rogalewskiego w latach 70. XX w., wiążąca pojęcie zagospodarowania turystycznego z przestrzenią. Od tego czasu rzadko podejmuje się próby nowego zdefiniowania pojęcia zagospodarowania turystycznego. Można jedynie zetknąć się z pewnymi modyfikacjami pierwotnej definicji, jednak są to zmiany mało znaczące, dlatego też przyjęto, że działalność mająca na celu przystosowanie środowiska geograficznego do potrzeb turystyki nazywa się zagospodarowaniem turystycznym. Zakres działalności dotyczy trzech podstawowych dziedzin [Rogalewski 1974, s. 7]:

- działalności mającej na celu ochronę i przystosowanie do potrzeb ruchu turystycznego walorów turystycznych, a więc tych elementów środowiska geograficznego, które stanowią właściwy cel przestrzenny wyjazdów turystycznych,

- działalności zmierzającej do zapewnienia możliwości dojazdu (dostępności komunikacyjnej) do obszarów, miejscowości i obiektów stanowiących cele wyjazdów turystycznych,

- działalności zmierzającej do zapewnienia turystom niezbędnych warunków egzystencji w miejscu lub na szlaku będącym celem podróży, głównie dotyczy to wyposażenia w odpowiednie urządzenia obsługowe, przede wszystkim w zakresie potrzeb noclegowo-żywieniowych.

Wynik powyższych działalności określany jest jako zespół urządzeń turystycznych, infrastruktura turystyczna lub baza materialna turystyki, czyli jako zagospodarowanie turystyczne. Pojęcia te, jak już wspomniano, stosowane są zamiennie w różnych publikacjach, wszystkie jednak dotyczą: wyposażenia określonego obszaru, szlaku lub miejscowości, umożliwiające zaspokojenie potrzeb turystycznych.

Zagospodarowanie turystyczne jest elementem planowania przestrzennego ujmowanym albo jako jedno z wielu jego składników, albo zagadnienie wiodące. Kwestie turystyczne występują zarówno w planach krajowych, jak też regionalnych i miejscowych. W rozważaniach dotyczących zagospodarowania turystycznego nie można pominąć koncepcji turystyki zrównoważonej. Istnieje między nimi ścisły związek. Dzięki wprowadzeniu odpowiednich kierunków polityki przestrzennej można bowiem stymulować na danym obszarze rozwój turystyki, propagując jednak takie jej formy, które nie będą zagrożeniem dla środowiska przyrodniczego, społecznego i kulturowego tego obszaru. Wyrazem tego procesu jest racjonalne zagospodarowanie przestrzeni turystycznej.

Podstawowy element i decydujące ogniwo zagospodarowania turystycznego istotnego elementu megaproduktu miasta - stanowi baza noclegowa. Jest ona tym 
składnikiem infrastruktury turystycznej, która z jednej strony warunkuje rozwój funkcji turystycznej na poszczególnych obszarach, z drugiej zaś umożliwia uprawianie różnych rodzajów turystyki, służąc zaspokajaniu potrzeb turystów. Wielkość bazy noclegowej jest uznawana za główny wskaźnik zdolności recepcyjnej obszaru oraz służy do oceny stopnia rozwoju funkcji turystycznej danej jednostki przestrzennej. Zdecydowana większość autorów zajmujących się zagospodarowaniem turystycznym wymienia urządzenia i usługi noclegowe jako najważniejszy rodzaj infrastruktury turystycznej oraz bardzo ważny składnik strukturalnego potencjału turystycznego [Defert 1988, Kowalczyk 2000, Szwichtenberg 2006].

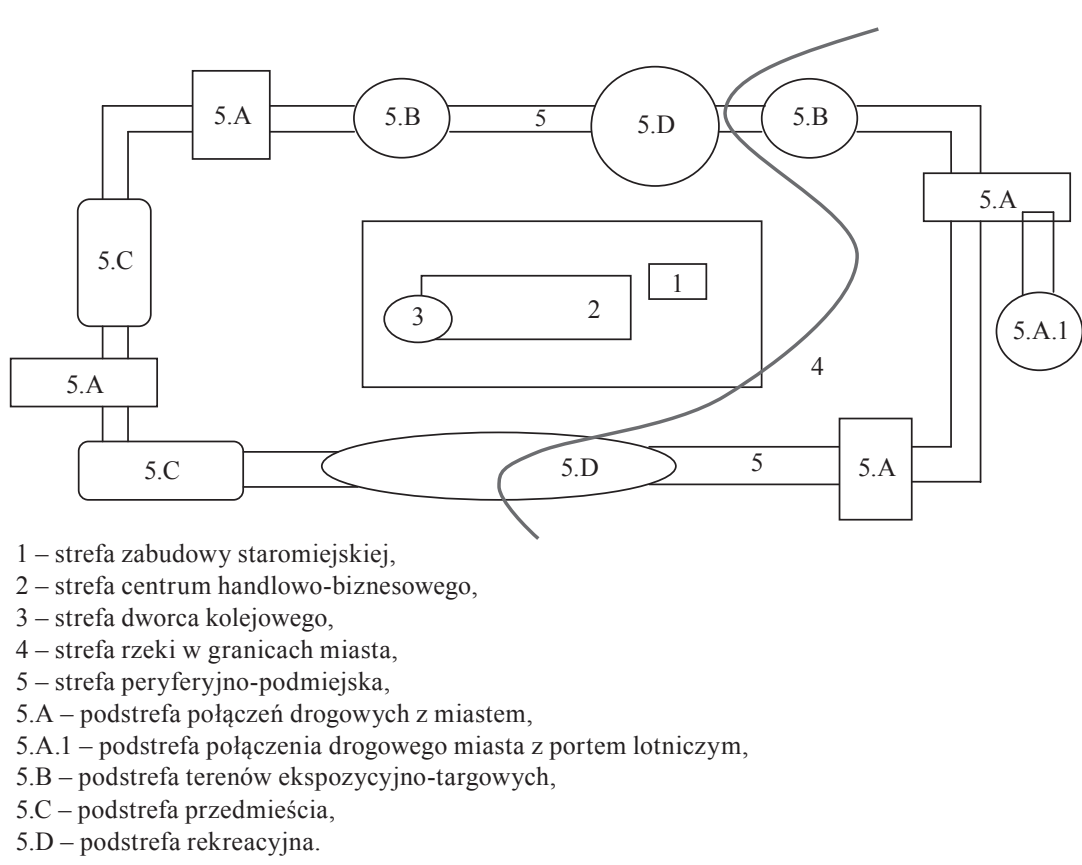

Rys. 3. Schemat ideowy podziału przestrzeni miejskiej ze względu na lokalizację hoteli Źródło: [Butowski 1996, s. 211].

Należy podkreślić, że w przypadku pozostałych elementów infrastruktury turystycznej, tj.: bazy żywieniowej (gastronomicznej), komunikacyjnej i bazy towarzyszącej, oprócz problemu z brakiem danych statystycznych występuje także problem związany z tym, że są one w największym stopniu paraturystyczne, a więc służące nie tylko turystom, ale także mieszkańcom. 
Na obszarze dużych miast o rozwiniętej funkcji turystycznej zauważa się znaczną koncentrację bazy noclegowej, co wynika z dużego zapotrzebowania na świadczone przez nią usługi. W zakresie rozmieszczenia obiektów noclegowych w dużych miastach obserwuje się pewne prawidłowości. W każdym ośrodku można wyróżnić obszary, na których występuje koncentracja hoteli. Zjawisko to jest ściśle związane z cechami tych części miast oraz funkcjami, jakie pełnią. W wielu miastach można wyodrębnić następujące strefy koncentracji bazy hotelowej (rys. 3) [Butowski 1993, s. 51-52]:

1) strefa zabudowy staromiejskiej, na której obszarze znajdują się zwykle najbardziej „wartościowe” zabytki miasta. Strefę tę charakteryzuje dobre zagospodarowanie turystyczne oraz bogata oferta turystyczna. Znajdują się tu przede wszystkim obiekty średniej i wyższej klasy. W tej części miast występują ponadto obiekty noclegowe dla turystyki młodzieżowej, jak np. domy turysty, schroniska młodzieżowe;

2) strefa centrum handlowo-biznesowego. W tej części miasta obserwuje się koncentrację hoteli wysokiej i średniej kategorii, które w większości przeznaczone są dla turystów podróżujących w celach służbowych. W tradycyjnych centrach targowych znajdują się tereny ekspozycyjne, które są powiązane funkcjonalnie $\mathrm{z}$ występującymi w bezpośrednim sąsiedztwie obiektami hotelowymi;

3) strefa dworców kolejowych, składająca się z kilku niezależnych od siebie podstref. W tych częściach miasta zlokalizowane są hotele średniej i niższej kategorii. Czasem znajdują się tutaj schroniska młodzieżowe i różnego rodzaju obiekty. W wielu wypadkach strefa ta pokrywa się z centrum handlowo-biznesowym lub jest w pobliżu jego sąsiedztwa. Wówczas w strefie tej występują obiekty o wyższej klasie;

4) strefa peryferyjno-podmiejska, w której można wyodrębnić trzy podsystemy:

- podstrefa połączeń drogowych z miastem, występująca bądź w granicach miasta, bądź poza nim (na obrzeżach). Sytuuje się tam nowoczesne i stosunkowo tanie obiekty noclegowe przystosowane do obsługi turystów zmotoryzowanych oraz strefę połączenia drogowego miasta z portem lotniczym znajdującym się w dużej odległości od miasta. Szczególną koncentrację hoteli obserwuje się wtedy w bezpośrednim sąsiedztwie portu lotniczego. Obiekty noclegowe na tych obszarach wchodzą często w skład dużych sieci handlowych i świadczą usługi o wysokim standardzie;

- strefa terenów ekspozycyjno-handlowych - w wielu miastach infrastruktura wystawiennicza zlokalizowana jest na obrzeżach i wiąże się z dużą koncentracją obiektów hotelowych średniej i niższej kategorii;

- strefa przedmieścia, gdzie występuje koncentracja obiektów hotelowych najniższym standardzie. 
Należy podkreślić, że w konkretnych dużych miastach nie zawsze występują wszystkie wymienione strefy bądź też może zdarzyć się trudność wyodrębnienia danej strefy, gdyż pokrywa się ona z inną.

\section{Wartość przestrzeni turystycznej - wybrane aspekty}

Przestrzeń ma wartość ekologiczną, społeczną i ekonomiczną. Jej wartość ekologiczna wynika z faktu, że jest ona miejscem przebiegu materialnych procesów biologicznych. Wartość społeczna generowana jest przez funkcje publiczne, jakie spełnia. Mogą to być funkcje mieszkaniowe, edukacyjne, komunikacyjne, handlowe, turystyczne - i od nich właśnie zależy wartość danej przestrzeni. Na wartość ekonomiczną składają się dwie wymienione wartości, ale także koniunktura gospodarcza danego obszaru. Jej wartości estetyczne i kulturowe, zadbane tereny zielone, odpowiednia forma zagospodarowania przyciągająca mieszkańców, inwestorów i turystów.

Przestrzeń turystyczna jest dobrem ograniczonym, lecz interpretacja tej cechy może być różna, biorąc pod uwagę wartość i cenę tej przestrzeni. Inną wartość ma przestrzeń z punktu widzenia użytkowników, jej właścicieli czy też władz publicznych. Ograniczoność, a więc do pewnego stopnia niepowtarzalność i unikatowość, ocenia się inaczej w zależności od tego, czy rozpatruje się ten aspekt w skali lokalnej, regionalnej, krajowej, czy międzynarodowej. Szczególnie w skali lokalnej i regionalnej widoczne jest duże zróżnicowanie przestrzeni turystycznej i jej cech, co prowadzi do złożonych mechanizmów wyznaczania jej wartości i w konsekwencji ceny. Skalę trudności pogłębia również fakt, że w ocenie wartości przestrzeni znaczącą rolę odgrywa czynnik subiektywny. Zewnętrznym wyrazem przestrzeni jest krajobraz ( $w$ ujęciu szeroko rozumianego środowiska naturalnego i kulturowego). Traktując krajobraz pod względem estetycznym, można stwierdzić, że jego wartość rośnie wraz ze wzrostem możliwości dostarczenia przeżyć estetycznych użytkownikom. Intensywność przeżyć estetycznych związanych z krajobrazem zależy od bardzo wielu elementów, takich np. jak: czytelność, harmonia, wystarczająco silne wrażenia, motywy budzące skojarzenia [Ocena i wycena... 2007, s. 56], które utrudniają znalezienie obiektywnych mierników wartości przestrzeni.

Miarą wartości ekonomicznej krajobrazu może być wartość zachowanego środowiska naturalnego i kulturowego w połączeniu z możliwością efektywnego i użytecznego wykorzystania przestrzeni - w tym przestrzeni turystycznej. Wartość przestrzeni turystycznej rozpatrywać należy na dwu płaszczyznach. $\mathrm{Z}$ jednej strony jest to możliwość efektywnego i użytecznego jej wykorzystania, z drugiej zaś dążenie do zachowania tych cech, które świadczą o jej niepowta- 
rzalności (unikatowości). Tak rozumiana wartość jest związana z funkcją, jaką przestrzeń pełni - zarówno rzeczywistą, jak też potencjalną (wynikającą m.in. $\mathrm{z}$ regulacji prawnych). W pewnym zakresie zagadnienia ekonomiczne regulowane są: na poziomie krajowym w koncepcji przestrzennego zagospodarowania kraju, na poziomie racjonalnym, w planach zagospodarowania przestrzennego województw, które powinny być skorelowane z uwarunkowaniami społeczno-gospodarczymi, w odniesieniu do gminy są to studia uwarunkowań i kierunków przestrzennego zagospodarowania oraz miejscowe plany zagospodarowania przestrzennego. Jednak tylko dla tych ostatnich sporządzana jest obowiązkowo prognoza skutków finansowych uchwalania planu [Ustawa... 2003].

Wartość przestrzeni można również rozpatrywać w kontekście możliwości zaspokajania określonych potrzeb, co odnosi się do właścicieli lub użytkowników, jak też może być ona rozumiana jako zdolność do generowania dóbr, tj. do generowania przychodu i uczestnictwa w wymianie towarowo-pieniężnej. $Z$ tego punktu widzenia można wyróżnić dwie kategorie: wartość jako dobro indywidualne oraz wartość jako dobro publiczne. Tak więc przestrzeń turystyczną i jej wartość można traktować w kontekście niniejszego artykułu przede wszystkim jako dobro publiczne [Wańkowicz 2010, s. 356]. Upraszczając, oznacza to, że nie ma możliwości wykluczenia kogokolwiek z możliwości korzystania z takiego dobra, wszyscy mają podobne prawa korzystania z niego, a administracja publiczna stanowi podmiot działań interwencyjnych zapewniających dostęp do dóbr publicznych [Stiglitz 2004, s. 150-151].

Biorąc pod uwagę cenę przestrzeni, należy podkreślić, że odnosi się ona do nieruchomości, a więc wyodrębnionych części gruntu wraz z ich zagospodarowaniem. Cena ta zależy od wartości zjawisk i zachowań rynkowych, tj. relacji podażowo-popytowych. Nieruchomość jest towarem specyficznym, ponieważ przedmiotem obrotu jest nie tylko grunt czy budynek, tylko prawo do nieruchomości. Tak więc obrót nieruchomościami staje się obrotem różnymi prawami określającymi sposób użytkowania oraz prawa i obowiązki właścicieli i innych użytkowników nieruchomości'. Specyfika uwidocznia się szczególnie w odniesieniu do nieruchomości turystycznych, tj. zagospodarowania turystycznego. Dla nieruchomości turystycznej odpowiednia jest lokalizacja na obszarach o wysokiej atrakcyjności turystycznej (wysoka wartość przestrzeni), na których nie przewiduje się innych inwestycji uciążliwych dla środowiska. Z tej przyczyny dla potencjalnych inwestorów ważne są informacje o tym, w jakim stopniu funkcja obszarów i strategie rozwoju są zbieżne z planami inwestycyjnymi związanymi z turystyką oraz czy dla danego obszaru jest zatwierdzony miejscowy plan

${ }^{1}$ Podkreślenia wymaga fakt, że twierdzenie to odnosi się nie do każdej kategorii przestrzeni, lecz do przestrzeni o określonym potencjale turystycznym. Nieostre jest rozgraniczenie tych kategorii. 
zagospodarowania przestrzennego. Istotnymi wskaźnikami są więc dla inwestorów zamiary i działania władz samorządowych i programy zadań rządowych składające się na strukturę planowania przestrzennego (zbieżność działalności inwestora z koncepcją rozwoju obszaru).

Uwzględniając strukturę elementów infrastruktury turystycznej, można stwierdzić, że udział podmiotów odpowiedzialnych za ich tworzenie jest różny, przede wszystkim ze względu na fakt ich przeznaczenia (do kogo są adresowane). Podmioty komercyjne tworzą i eksploatują obiekty przeznaczone przede wszystkim dla potrzeb swoich klientów - turystów. Natomiast podmioty publiczne (jednostki samorządu terytorialnego i organy państwowe) rozwijają infrastrukturę techniczno-społeczną nie tylko na potrzeby obsługi ruchu turystycznego, ale przede wszystkim dla celów tworzenia warunków rozwoju obszarów z myślą o społeczeństwie i gospodarce tych układów przestrzennych.

Należy zwrócić uwagę na potrzebę, a wręcz konieczność kształtowania odpowiedniej współpracy między podmiotami komercyjnymi a sektorem publicznym, co pozwoli na odpowiednie z punktu widzenia różnych kryteriów zagospodarowanie turystyczne, a w konsekwencji kształtowanie odpowiedniego wizerunku obszaru oraz stworzenie i wykreowanie własnego produktu turystycznego.

Poprawnie zaprojektowany system zarządzania przestrzenią, w tym przestrzenią turystyczną powinien uwzględniać rachunek ekonomiczny w mikroi makroskali. W skali makro rachunek ten powinien bilansować się dodatnio lub do zera (czasowo może być ujemny) zarówno w sektorze publicznym, jak i prywatnym. W skali mikro powinien bilansować się dodatnio lub do zera (czasowo może być ujemny) w sektorze prywatnym, natomiast może być ujemny w sektorze publicznym. Jest to związane z możliwością uczestnictwa w kosztach także tych, którzy nie odnoszą korzyści bezpośrednich (redystrybucja środków z innych obszarów) [Wańkowicz 2010, s. 357].

\section{Zakończenie}

Marketing stosowany w relacjach między jednostką przestrzenną a poszczególnymi jego odbiorcami skutkuje postrzeganiem poszczególnych obszarów jako produktów w rozumieniu marketingowym. Biorąc pod uwagę zróżnicowane potrzeby odbiorców oferty jednostki terytorialnej, produkt tej jednostki określany jest mianem „megaproduktu”. Jest on dzielony na subprodukty funkcjonalne, wśród których znajduje się m.in. turystyka i jej komponenty.

Rozwój funkcji turystycznej zapewnia infrastruktura techniczna stanowiąca ważny element strukturalnego potencjału turystycznego. W kontekście marketingu terytorialnego zagospodarowanie turystyczne będące składową zagospoda- 
rowania przestrzennego rozumiane jest jako jeden z najistotniejszych elementów produktu turystycznego miasta, obok walorów przyrodniczych i kulturowych. Zespół obiektów i urządzeń stanowiących wyposażenie określonego terenu umożliwiających zaspokojenie potrzeb ruchu turystycznego ukierunkowany jest na poprawę atrakcyjności turystycznej. Zagospodarowanie turystyczne jako element produktu turystycznego obszaru stanowi subprodukt megaproduktu miasta będącego skumulowaną sumą wszystkich produktów cząstkowych zarówno materialnych, jak i niematerialnych zdolnych do generowania potencjalnych korzyści oferowanych konkretnemu nabywcy w wyniku procesu wymiany.

Zagospodarowanie turystyczne pod względem ekonomicznym ma znaczący wpływ na wartość przestrzeni turystycznej wycenianej zarówno z punktu widzenia właścicieli lub użytkowników, jak również całej gospodarki. Najbardziej zobiektywizowanym miernikiem zagospodarowania turystycznego jest baza noclegowa, która stanowi część gospodarki narodowej generującej przychody z rynku turystycznego. Kwantyfikacja wartości przestrzeni turystycznej jest trudna do obiektywnego przeprowadzenia. Użytkownicy danej przestrzeni turystycznej będą podkreślali jej bezcenny charakter ze względu na wartości przyrodnicze i historyczno-kulturowe, inwestorzy będą ukierunkowywali wycenę pod kontem korzyści lokalizacji a administracja publiczna jako zdolność generowania dochodów oraz wpływ na wielkość PKB.

\section{Literatura}

Bosiacki S. [2010], Potencjat turystyczny Poznania jako podstawa kreowania produktów markowych, Zeszyty Naukowe Uniwersytetu Szczecińskiego, nr 591, Ekonomiczne Problemy Usług, nr 53, Szczecin.

Butowski L. [1993], Baza hotelowa w wielkim mieście europejskim: wielkość, rozmieszczenie przestrzenne, struktura, „Problemy Turystyki”, vol. XVI, nr 3.

Butowski L. [1996], Duże miasta europejskie jako obszary recepcji turystycznej, KPZK Biuletyn I.174, Warszawa.

Defert P. [1988], Nouvelle réflexions sur le Taut de fonction touristique, Téoros. Revue de recherche en tourisme, 7,3, Wydawnictwo Université du Québec à Montreal.

Kaczmarek J., Stasiak A., Włodarczyk B. [2005], Produkt turystyczny, PWE, Warszawa. Kompendium wiedzy o turystyce [2002], red. G. Gołembski, Wydawnictwo PWN, Warszawa-Poznań.

Kornak S.A., Rapacz A. [2001], Zarządzanie turystyka i jej podmiotami w miejscowości i regionie, Wydawnictwo Akademii Ekonomicznej im. Oskara Langego we Wrocławiu, Wrocław.

Kotler Ph., Brower J., Makers J. [1999], Marketing for Hospitality and Tourism, Prentice Hall, Upper Saddle River.

Kowalczyk A. [2000], Geografia turyzmu, Wydawnictwo Naukowe PWN, Warszawa Kozak M., Pyszkowski A., Szewczyk R. [2000], Słownik rozwoju regionalnego, PARR, Warszawa. 
Marketing terytorialny. Możliwości aplikacji i kierunki rozwoju [2005], red. H. Szulce, M. Florek, Wydawnictwo AE w Poznaniu, Poznań.

Markowski T. [1997], Miasto jako produkt - wybrane aspekty marketingu miasta [w:] Marketing terytorialny. Strategiczne wyzwania dla miast i regionów, red. T. Domański, Centrum Badań i Studiów Francuskich, Instytut Studiów Międzynarodowych, Uniwersytet Łódzki, Łódź.

Myrdal G. [1959], Economic Theory and Under-developed Regions, Gerald Duckworth: London.

Niezgoda A. [2006], Obszar recepcji turystycznej w warunkach rozwoju zrównoważonego, Prace Habilitacyjne, nr 24, Akademia Ekonomiczna w Poznaniu, Poznań.

Ocena i wycena krajobrazu. Wybrane problemy rynkowej oceny $i$ wyceny krajobrazu wiejskiego, miejskiego i stref przejściowych [2007], red. T. Bajerowski, Educaterra, Olsztyn.

Regionalne aspekty rozwoju turystyki [1999], red. G. Gołembski, Wydawnictwo Naukowe PWN, Warszawa.

Rogalewski O. [1994], Zagospodarowanie turystyczne, Wydawnictwo Szkolne i Pedagogiczne, Warszawa.

Schwichtenberg A. [2006], Gospodarka turystyczna polskiego wybrzeża, Monografia Wydziału Ekonomii i Zarządzania, nr 121, Wydawnictwo Uczelniane Politechniki Koszalińskiej, Koszalin.

Stiglitz J.E. [2004], Ekonomia sektora publicznego, Wydawnictwo Naukowe PWN, Warszawa.

Szromnik A. [1997], Marketing turystyczny - geneza, rynki docelowe i podmioty oddziatywania [w:] Marketing terytorialny. Strategiczne wyzwania dla miast i regionów, red. T. Domański, Centrum Badań i Studiów Francuskich, Instytut Studiów Międzynarodowych, Uniwersytet Łódzki, Łódź.

Szromnik A. [2002], Marketing miast i regionów (marketing regionalny) - geneza, cechy i cele [w:] Marketing w rozwoju regionu, red. J. Karwowski, Uniwersytet Szczeciński, Szczecin.

Turystyka [2007], red. W. Kurek, Wydawnictwo Naukowe PWN, Warszawa.

Ustawa z dnia 27 marca 2003 r. o planowaniu i zagospodarowaniu przestrzennym, Dz.U. 2003, nr 80, poz. 717, ze zm.

Wańkowicz W. [2010], Planowanie przestrzeni o wysokich walorach krajobrazowych, Problemy ekonomiczne, Prace Komisji Krajobrazu Kulturowego, nr 14, Komisja Krajobrazu Kulturowego, PTG, Sosnowiec.

Wołek M. [2010], Marketing miasta poprzez sektor przedsiębiorczości. Cechy atrakcyjności inwestycyjnej miasta Tczew,www.tczew.pl/pdf/tczew_prez_MW_6_10_2010. ppt (dostęp: 1.12.2013).

\section{Tourist Development as a Factor in the Economic Formation of Tourist Area Products}

As a multidimensional phenomenon, tourism is an important determinant of the economic development of cities and regions. This study pays particular attention to the development of tourism, which is part of the supply side of the tourism market. It presents the economic aspects of the management of tourism space, highlighting the optimal use 
of assets and resources a given spatial unit has, including the substantial and constantly evolving development of tourism. The purpose of this article is to present tourism development as part of the tourism product area, constituting one component of a city's megaproduct, and the presentation of the economic aspects of tourism area management. The discussion introduces the basics of a marketing approach to the development of the tourism specific reception area product, and more precisely a methodical concept for defining such a product. The article is of a mainly theoretical nature.

Keywords: tourism, tourism development, mega-product, territory touristic product. 